\title{
Analisis Kemampuan Pemecahan Masalah Siswa Berdasarkan Kemampuan Awal Matematika
}

\author{
Mulia Suryani ${ }^{*}$, Lucky Heriyanti Jufri ${ }^{2}$ dan Tika Artia Putri ${ }^{3}$ \\ 1*2,3Program Studi Pendidikan Matematika, STKIP PGRI Sumatera Barat \\ Jalan Gn. Pangilun, Padang Utara, Padang, Sumatera Barat, Indonesia \\ $1^{*}$ muliasuryani@gmail.com
}

Artikel diterima: 25-10-2019, direvisi: 28-01-2020, diterbitkan: 31-01-2020

\begin{abstract}
Abstrak
Rendahnya kemampuan pemecahan masalah matematika siswa menyebabkan siswa kurang mampu menyelesaikan soal yang bersifat non rutin dan siswa masih kurang mengembangkan ide dan kemampuan yang dimilikinya. Penelitian ini bertujuan untuk mengetahui kemampuan pemecahan masalah matematika siswa melalui model Problem Based Learning berdasarkan Kemampuan Awal Matematika (KAM) siswa. Metode penelitian yang digunakan adalah kualitatif. Hasil penelitian ini menunjukkan bahwa kemampuan pemecahan masalah matematika siswa melalui model Problem Based Learning menjadi lebih baik. Sampel dalam penelitian ini adalah siswa kelas VIII-7 SMP Negeri 12 Padang yang terdiri dari 32 orang. Siswa yang awalnya berkemampuan rendah meningkat menjadi siswa berkemampuan sedang dengan peningkatan sebesar 75 \%. Siswa yang awalnya tergolong berkemampuan sedang meningkat menjadi siswa berkemampuan tinggi sebesar $26 \%$. Siswa sudah mampu 1) memahami masalah, 2) menyusun rencana penyelesaian, 3) melaksanakan penyelesaian, dan 4) mengecek kembali jawaban.

Kata Kunci : Kemampuan Awal Matematika, Kemampuan Pemecahan Masalah Matematika, Problem Based Learning.
\end{abstract}

\section{Analysis of Students' Problem Solving Abilities Based on Early Mathematical Ability}

\begin{abstract}
The lack of students' mathematical problem-solving skills causes students to be less able to solve problems that are non-routine and students are still lacking in developing their ideas and abilities. This study aims to determine students 'mathematical problem-solving abilities through the Problem Based Learning model based on students' Early Mathematical Ability (KAM). The research method used is qualitative. The results of this study indicate that students' mathematical problem-solving abilities through the Problem Based Learning model are better. The sample in this study were students of class VIII-7 Middle School 12 Padang consisting of 32 people. Students who were initially low-skilled increased to moderate-capable students with an increase of $75 \%$. Students who were initially classified as capable were increasing to high-ability students by $26 \%$. Students can 1) understand the problem, 2) draw up a settlement plan, 3) carry out the solution, and 4) re-check the answers.

Keywords: Early Mathematical Ability, Mathematical Problem Solving Ability, Problem Based Learning.
\end{abstract}


http://journal.institutpendidikan.ac.id/index.php/mosharafa

\section{Pendahuluan}

Pembelajaran merupakan suatu upaya yang menciptakan kondisi belajara yang dapat memaksimalkan siswa dalam mengikuti proses pembelajaran. Menurut (Suprihatiningrum, 2013) "Pembelajaran adalah serangkaian kegiatan yang melibatkan informasi dan lingkungan yang disusun secara terencana untuk memudahkan siswa dalam belajar". Dapat disimpulkan bahwa pembelajaran adalah upaya guru untuk mendorong siswa atau memfasilitasi siswa belajar serta peran guru sebagai fasilitator untuk mengkontruksi pengetahuannya.

Matematika adalah salah satu mata pelajaran yang wajib dipelajari oleh siswa (Afriansyah, dkk., 2019). Kualitas pendidikan sering dijadikan sebagai barometer perkembangan suatu negara. Kemampuan siswa dalam menyelesaikan masalah matematika, sains, dan membaca serta aplikasinya dalam kehidupan seharihari dijadikan sebagai gambaran baik atau tidaknya kualitas pendidikan khusus untuk usia wajib belajar (Johar, 2011). Hal ini menunjukkan pentingnya pembelajaran matematika untuk diajarkan pada setiap jenjang kelas di sekolah agar mencetak siswa yang handal dalam menghadapi perubahan zaman melalui penguasaan matematika. Nikson dalam (Muliyardi, 2002) mengatakan "Pembelajaran matematika adalah upaya untuk mengkontruksi konsep-konsep atau prinsip-prinsip dalam matematika dengan kemampuannya sendiri melalui proses internalisasi sehingga konsep atau prinsip itu terbangun kembali".

Sejalan dengan Permendiknas Nomor 58 Tahun 2014 bahwa matematika merupakan universal yang berguna bagi kehidupan manusia dan juga mendasari perkembangan teknologi modern, serta mempunyai peran penting dalam berbagai disiplin dan memajukan daya pikir manusia. Salah satu dari kemampuan matematis yang harus dimiliki siswa adalah kemampuan pemecahan masalah matematika. Kemampuan pemecahan masalah merupakan salah satu tujuan pembelajaran matematika yang harus dicapai oleh siswa yang terdapat pada Peraturan Menteri Pendidikan Nasional No 22 Tahun 2006 (Utami \& Wutsqa, 2017). Kemampuan pemecahan masalah mengacu kepada usaha seseorang untuk mencapai tujuan karena mereka tidak memiliki solusi otomatis yang langsung dapat memecahkan masalah. Suatu masalah memiliki tujuan yaitu apa yang coba didapatkan si pemecah masalah untuk mencapai tujuan. (Burton, 1980) mengatakan bahwa pemecahan masalah adalah kegiatan individu atau kelompok kecil yang paling efisien ketika dilakukan secara kooperatif dengan kesempatan gratis untuk berdiskusi.

Kemampuan pemecahan masalah adalah suatu kecakapan atau potensi yang dalam diri siswa sehingga ia dapat menyelesaikan permasalahan dan dapat mengaplikasikannya dalam kehidupan sehari-hari (Gunantara, Suarjana, \& 
Riastini, 2014). Jadi, dapat disimpulkan bahwa kemampuan pemecahan masalah merupakan kemampuan dasar dalam proses pembelajaran. Pada proses pembelajaran guru harus mampu merangsang kreativitas siswa dalam memecahkan suatu masalah (Afriansyah, 2016). Kemampuan pemecahan masalah sangat penting bagi siswa karena dengan siswa mampu menyelesaikan suatu masalah siswa memperoleh pengalaman, menggunakan pengetahuan dan keterampilan yang sudah dimiliki oleh siswa untuk diterapkan dalam kehidupan sehari-hari (Elita, Habibi, Putra, \& Ulandari, 2019).

Kenyataannya yang ditemukan disekolah menunjukkan kemampuan pemecahan masalah matematika siswa masih tergolong rendah (Asih \& Ramdhani, 2019). Siswa kurang mampu menyelesaikan soal pemecahan masalah (Sopian \& Afriansyah, 2017). Pada saat guru meminta siswa untuk menyelesaikan soal non rutin siswa kurang mampu menyelesaikannya. Soal non rutin merupakan soal yang untuk menyelesaikannya diperlukan pemikiran lebih lanjut. Dalam pembelajaran guru tidak pernah mengorientasikan siswa pada suatu masalah sehari-hari yang dekat dengan kehidupan siswa dan tidak memperhatikan kemampuan pemecahan masalah siswa. Dalam mengajar guru cenderung kurang memperhatikan kemampuan awal siswa. Selain itu, guru matematika tidak melakukan pengajaran bermakna (Afriansyah, 2014) secara maksimal yang berakibat pola belajar siswa cenderung menghafal.

Kemampuan awal siswa merupakan kemampuan yang telah ada didalam diri siswa sebelum ia memulai pembelajaran. Kemampuan awal dalam mata pelajaran matematika penting untuk diketahui guru sebelum memulai pembelajaran (Gais \& Afriansyah, 2017). Hal ini berguna untuk mengetahui apakah siswa mempunyai pengetahuan prasyarat (prerequisite) untuk mengikuti pembelajaran dan sejauh mana siswa telah mengetahui materi yang akan disajikan, sehingga guru dapat merancang pembelajaran lebih baik.

Branca (Sumarmo, 1994) berpendapat bahwa pemecahan masalah dapat diartikan dengan menggunakan interpretasi umum yaitu pemecahan masalah sebagai tujuan, proses, dan keterampilan dasar. Pemecahan masalah sebagai tujuan menyangkut alasan mengapa matematika itu diajarkan. Dalam interpretasi ini, pemecahan masalah bebas dari soal, prosedur, metode atau isi khusus yang menjadi pertimbangan utama adalah bagaimana cara menyelesaikan masalah yang merupakan alasan mengapa matematika itu diajarkan. Pemecahan masalah sebagai proses merupakan suatu kegiatan yang lebih mengutamakan pentingnya prosedur, langkah-langkah 
http://journal.institutpendidikan.ac.id/index.php/mosharafa

strategi yang ditempuh oleh siswa dalam

menyelesaikan masalah dan akhirnya

\section{Metode}

dapat menemukan jawaban soal bukan

Metode penelitian yang digunakan hanya pada jawaban itu sendiri (Sumartini, 1981).

Berdasarkan beberapa pendapat diatas maka indikator pemecahan masalah adalah metode pre-eksperimen. Menurut (Arikunto, 2010) bahwa "Penelitian Preexperimental seringkali dipandang sebagai eksperimen yang tidak sebenarnya atau matematis yang digunakan yaitu menurut sering disebut dengan istilah quasi Polya dalam (Ariani, Hartono, \& experiment". Penelitian ini merupakan Hiltrimartin, 2017) adalah: (1) memahami masalah (2) merencanakan pemecahan penelitian deskriptif dengan pendekatan kualitatif yang di uji cobakan di kelas VIII.7 masalah; (3) menyelesaikan masalah SMP Negeri 12 Padang semester ganjil sesuai rencana (4) memeriksa kebenaran tahun pelajaran 2019/2020 yang hasil atau jawaban. berjumlah 32 siswa. Pemilihan subjek

Tabel 1.

Rubrik Penilaian Kemampuan Pemecahan Masalah

\begin{tabular}{|c|c|c|}
\hline Aspek yang Dinilai & Reaksi terhadap Soal/Masalah & Skor \\
\hline Memahami masalah & $\begin{array}{l}\text { a. Tidak ada jawaban sama sekali } \\
\text { b. Menuliskan diketehui/ditanya/model tetapi salah atau } \\
\text { tidak memahami sama sekali } \\
\text { c. Memahami informasi atau permasalahan dengan kurang } \\
\text { tepat/lengkap } \\
\text { d. Berhasil memahami masalah secara menyeluruh }\end{array}$ & $\begin{array}{l}0 \\
1\end{array}$ \\
\hline $\begin{array}{l}\text { Menyusun rencana } \\
\text { penyelesaian }\end{array}$ & $\begin{array}{l}\text { a. Tidak ada urutan langkah penyelesaian } \\
\text { b. Strategi/langkah penyelesaian ada tetapi tidak relevan } \\
\text { atau tidak/belum jelas } \\
\text { c. Strategi/langkah penyelesaian mengarah pada jawaban } \\
\text { yang benar tetapi tidak lengkap atau jawaban salah } \\
\text { d. Menyajikan langkah penyelesaian yang benar }\end{array}$ & $\begin{array}{l}0 \\
1\end{array}$ \\
\hline $\begin{array}{l}\text { Melaksanakan } \\
\text { penyelesaian }\end{array}$ & $\begin{array}{l}\text { a. Tidak ada penyelesaian sama sekali } \\
\text { b. Ada penyelesaian, tetapi prosedur tidak jelas/salah } \\
\text { c. Menggunakan prosedur tertentu yang benar tetapi } \\
\text { perhitungan salah/kurang lengkap } \\
\text { d. Menggunakan prosedur tertentu yang benar }\end{array}$ & $\begin{array}{l}0 \\
1 \\
2\end{array}$ \\
\hline $\begin{array}{l}\text { Mengecek kembali } \\
\text { jawaban }\end{array}$ & $\begin{array}{l}\text { a. Jika tidak menuliskan kesimpulan dan tidak melakukan } \\
\text { pengecekan terhadap proses juga hasil jawaban } \\
\text { b. Jika menuliskan kesimpulan dan/atau melakukan } \\
\text { pengecekan terhadap proses dengan kurang tepat atau } \\
\text { jika hanya menuliskan kesimpulan saja atau melakukan } \\
\text { pengecekan terhadap proses saja dengan tepat } \\
\text { c. Jika menuliskan kesimpulan dan melakukan pengecekan } \\
\text { terhadap proses dengan tepat }\end{array}$ & 0 \\
\hline
\end{tabular}

Sumber: (Adopsi Upu, 2003) 
penelitian menggunakan teknik purposive sampling. Berdasarkan pertimbangan yang dilakukan dalam pemilihan sampel, dipilih kelas VIII.7 karena nilai ketuntasan ujian semester 2 siswa lebih rendang dibandingkan dengan kelas lainya.

Instrumen penelitian meliputi tes akhir dan catatan lapangan. Menurut (Moleong, 2010), suatu penelitian kualitatif mengandalkan pengamatan dan wawancara dalam pengumpulan data dilapangan. Pada waktu berada dilapangan peneliti membuat catatan, setelah pulang ke rumah atau tempat tinggal barulah menyusun catatan lapangan". Disimpulkan bahwa catatan lapangan merupakan catatan tertulis mengenai apa yang didengar, dilihat, dialami, dan dipikirkan dalam rangka mengumpulkan data dan refleksi terhadap data dalam penelitian kualitatif. Sedangkan tes akhir digunakan sebagai alat ukur untuk melihat kemampuan pemecahan masalah matematika siswa. Tes akhir terdiri dari 5 soal, setiap soal merupakan soal pemecahan masalah. Sebelum soal digunakan, soal sudah di uji cobakan disekolah yang sama dan sudah diukur tingkat kesukaran, daya pembeda maupun reabilitas soal untuk melihat soal dapat digunakan sebagai alat pengumpulan data. Catatan lapangan digunakan untuk memperkuat sumber data yang ada.

Teknik analisis pada penelitian ini menggunakan teknik analisis data kemampuan pemecahan masalah. Data hasil tes kemampuan pemecahan masalah dianalisis menggunakan rubrik penskoran pemecahan masalah berdasarkan langkahlangkah kemampuan pemecahan masalah menurut Polya (lihat tabel 1).

\section{Hasil dan Pembahasan}

Berdasarkan hasil ujian tes akhir kemampuan pemecahan masalah secara keseluruhan tergolong cukup baik. Dari 32 siswa yang mengikuti tes akhir $94 \%$ siswa sudah melewati batas nilai Kriteria Ketuntasan Maksimal (KKM) dengan nilai tertinggi yaitu 100 . Sedangkan $6 \%$ siswa belum memenuhi Kriteria Ketuntasan Maksimal (lihat tabel 2).

Hal ini juga terlihat dari kemampuan siswa. Nilai rata-rata siswa yang berkemampuan tinggi yaitu 98,18 dengan simpangan baku 2,25 artinya sebaran nilai siswa yang berkemampuan tinggi tidak begitu menyebar dibandingkan dengan anak yang berkemampuan sedang, nilai

Tabel 2.

Rata-rata Kemampuan Pemecahan Masalah Matematika Siswa

\begin{tabular}{ccccc}
\hline Tes & $\overline{\boldsymbol{X}}$ & $\boldsymbol{S}$ & $\boldsymbol{X}_{\text {Maks }}$ & $\boldsymbol{X}_{\text {Min }}$ \\
\hline Tes & 86,28 & 9,68 & 100 & 67 \\
Akhir & & & &
\end{tabular}

Tabel 3.

Rekapitulasi nilai Tes Akhir Kemampuan Pemecahan Masalah

\begin{tabular}{cccc|}
\hline No & $\begin{array}{c}\text { Kemampuan } \\
\text { Tinggi }\end{array}$ & $\begin{array}{c}\text { Kemampuan } \\
\text { Sedang }\end{array}$ & $\begin{array}{c}\text { Kemampuan } \\
\text { Rendah }\end{array}$ \\
\hline$\overline{\boldsymbol{X}}$ & 98,18 & 84,60 & 73 \\
\hline $\boldsymbol{S}$ & 2,25 & 5,48 & 2,88 \\
\hline
\end{tabular}


http://journal.institutpendidikan.ac.id/index.php/mosharafa

rata-rata siswa tersebut berkisar diantara 98,18 . Sedangkan nilai rata-rata siswa yang berkemampuan sedang yaitu 84,60 dengan simpangan baku 5,48 artinya nilai siswa yang berkemampuan sedang lebih menyebar dari nilai 84,60. Selanjutnya, nilai rata-rata siswa yang berkemampaun rendah yaitu 73 dengan simpangan baku 2,88 artinya nilai siswa berkisar diantara 73 (lihat tabel 3).

Berdasarkan hasil analisis data terlihat jumlah siswa berdasarkan tingkat kemampuan siswa sebelum dan sesudah diberi perlakuan Model Problem Based Learning (lihat tabel 4).

Model Problem Based Learning ini terhadap kemampuan pemecahan masalah paling memberikan pengaruh terhadap siswa yang berkemampuan tinggi. Sebelum diberi perlakuan Model Problem Based Learning siswa berkemampuan tinggi berjumlah 5 orang, setelah diberi perlakuan siswa berkemampuan tinggi menjadi 9 orang. Sedangkan 2 orang siswa yang awalnya berkemampuan tinggi menurun menjadi siswa yang berkemampuan sedang dan 3 orang siswa menempati posisi yang sama. Selanjutnya, siswa yang berkemampuan

Tabel 4.

Jumlah Siswa Berdasarkan KAM sebelum dan sesudah diberi Perlakuan Model Problem Based

\begin{tabular}{ccc}
\hline $\begin{array}{c}\text { Learning } \\
\text { Kemampuan } \\
\text { Siswa }\end{array}$ & $\begin{array}{c}\text { SEBELUM } \\
\text { DIBERI } \\
\text { PERLAKUAN }\end{array}$ & $\begin{array}{c}\text { SESUDAH } \\
\text { DIBERI } \\
\text { PERLAKUAN }\end{array}$ \\
\hline TINGGI & 5 & 9 \\
\hline SEDANG & 23 & 15 \\
\hline RENDAH & 4 & 6
\end{tabular}

sedang sebelum diberi perlakuan model Problem Based Learning siswa berkemampuan sedang berjumlah 23 orang, setelah diberi perlakuan siswa berkemampuan sedang menjadi 17 orang. 5 dari 23 siswa yang berkemampuan sedang meningkat menjadi siswa berkemampuan tinggi. Sedangkan, 4 orang siswa yang awalnya berkemampuan sedang menurun menjadi siswa yang berkemampuan rendah dan 12 orang siswa menempati posisi yang sama. Model Problem Based Learning juga sangat berpengaruh terhadap pemecahan masalah pada siswa yang berkemampuan rendah. Dari 4 siswa yang awalnya berkemampuan rendah, 3 orang meningkat menjadi siswa berkemampuan sedang. Karena siswa berkemampuan rendah juga sangat berpartispasi dan lebih bersemangat ketika diberikan soal pemecahan masalah ketika berdiskusi kelompok. Tetapi, 1 diantara 4 orang siswa yang awalnya berkemampuan rendah tetap menempati posisi yang sama.

\section{a. Siswa Berkemampuan Tinggi}

Berdasarkan nilai Ujian Semester 2, siswa yang berkemampuan tinggi berjumlah 5 orang. Setelah diberikan tes akhir siswa yang tergolong berkemampuan tinggi menjadi 9 orang. Kemampuan pemecahan masalah pada siswa yang berkemampuan tinggi dalam menyelesaikan permasalahan tergolong baik. Hal ini ditunjukkan dari lembar jawaban siswa berkemampuan tinggi, mereka dapat menyelesaikan soal sesuai 
dengan indikator kemampuan pemecahan masalah. Tetapi, 2 diantara 5 orang yang tergolong berkemampuan tinggi menurun menjadi berkemampuan sedang. Salah satunya siswa yang bernama MS, siswa tersebut terkendala dibagian merencanakan masalah sehingga pada tahap menyelesaikan masalah siswa tersebut mendapatkan hasil yang salah. Sebagaimana yang terlihat pada lembar jawaban siswa yang bernama MS. Lembar jawaban siswa dapat dilihat pada Gambar 1.

Berdasarkan Gambar 1 siswa tersebut sudah mampu untuk mengindentifikasi dan memahami soal secara menyeluruh serta menemukan apa yang diketahui dan ditanya seperti jumlah 2 suku pertama adalalah 6, jumlah 4 suku pertama adalah 54. Selanjutnya siswa tersebut tidak menyusun rencana penyelesaian. Dimana ia langsung saja membuat penyelesaian tanpa membuat perencanaan terlebih

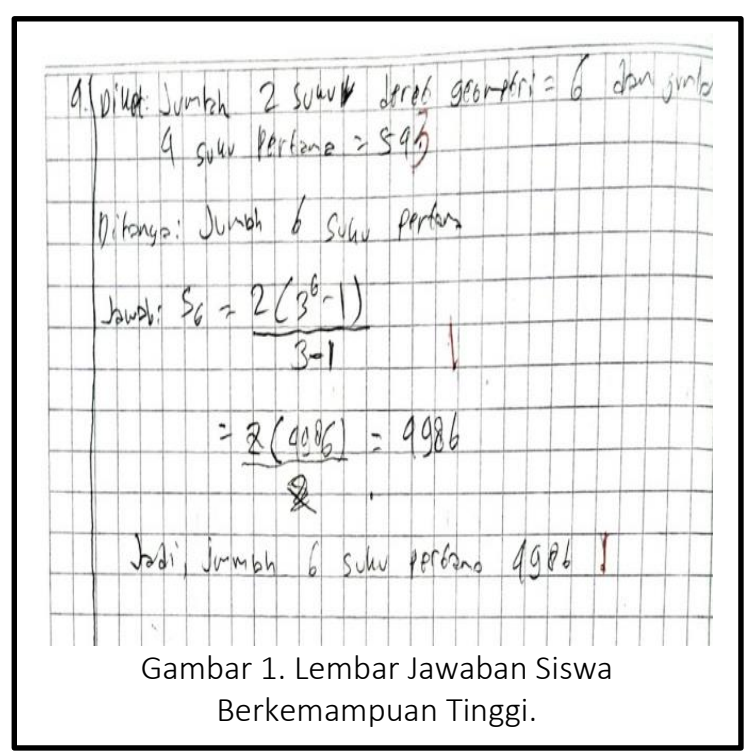

dahulu. Siswa tersebut langsung saja mencari $S_{6}$ atau jumlah 6 suku pertama, untuk menyelesaikan soal tersebut, seharusnya dicari dulu $r$ atau rasionya, lalu setelah didapatkan rasionya, siswa harus mencari $U_{1}$ atau suku pertamanya terlebih dahulu. Sehingga jawaban yang dibuat oleh siswa tersebut mendapatkan hasil yang salah. Lalu, ia menuliskan kesimpulan dan melakukan pengecekan terhadap proses dengan kurang tepat. Hasil wawancara dengan MS, ia mengatakan bahwa "saya kurang memahami soal yang diberikan, dan saya kira dengan memasukkan langsung ke dalam rumus akan mendapatkan hasil yang benar". Jadi, dapat disimpulkan bahwa siswa yang awalnya tergolong berkemampuan tinggi menurun menjadi berkemampuan sedang dikarenakan siswa tersebut kurang memahami apa yang dimaksudkan pada soal, sehingga ia kesulitan ketika membuat perencanaan masalah terlebih dahulu, sehingga ketika ia membuat penyelesaian hasil yang didapatkan salah.

\section{b. Siswa Berkemampuan Sedang}


http://journal.institutpendidikan.ac.id/index.php/mosharafa

Berdasarkan nilai ujian semester 2, menuliskan variabel tertentu seperti $U_{2}=6$ siswa yang tergolong berkemampuan sedang ada 23 orang. Setelah diberikan ujian tes akhir terdapat 17 orang siswa yang tergolong kedalam berkemampuan sedang, 12 diantaranya tetap menempati posisi yang sama. Tetapi, 6 diantara 17 siswa yang tergolong berkemampuan sedang meningkat menjadi siswa berkemampuan tinggi. Hasil ujian salah satu siswa yang berinisial DS dapat dilihat pada Gambar 2.

Berdasarkan Gambar 2, DS mampu menyelesaikan soal sesuai dengan indikator kemampuan pemecahan masalah. Kemampuan pemecahan masalah siswa tersebut tergolong cukup baik. Siswa mampu memahami soal dan membuat apa yang diketahui dan ditanya. DS telah berhasil memahami masalah secara menyeluruh. DS langsung

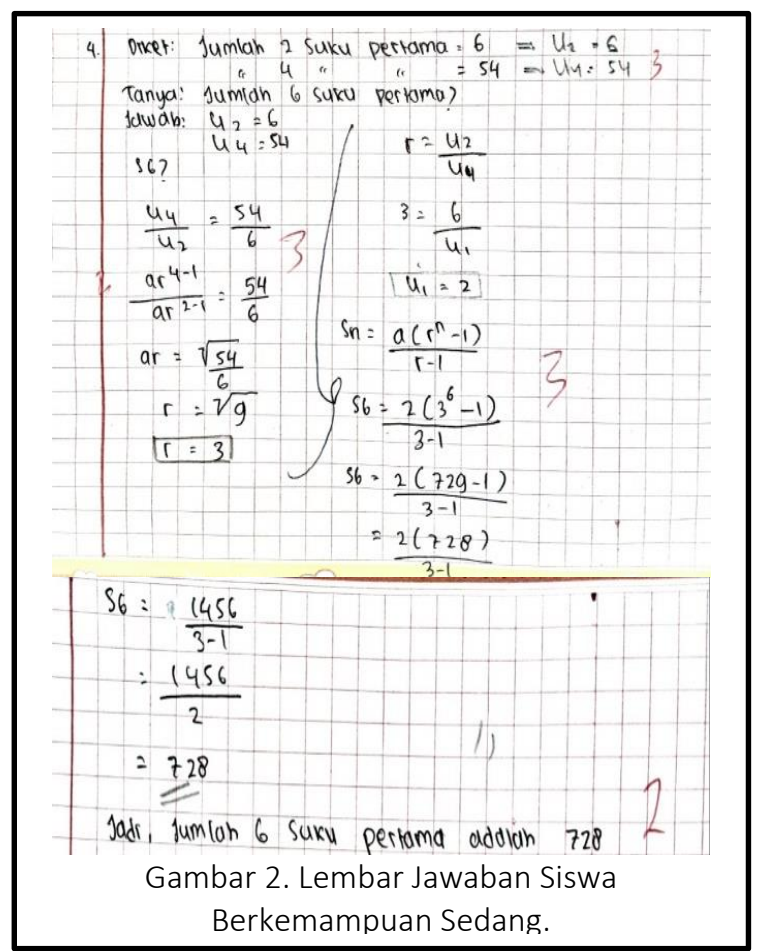
dan $U_{4}=54$. Selanjutnya siswa melanjutkan ke tahap menyusun rencana. DS sudah mampu membuat rencana untuk menyelesaikan suatu permasalahan dengan benar. Seperti yang terlihat pada Gambar 24, awalnya ia mencari $r$ terlebih dahulu dengan cara membagi $U_{4}$ dan $U_{2}$ lalu didapatkan $r=3$. DS mampu menyajikan langkah penyelesaian dengan benar. DS mampu menyelesaikan soal menggunakan prosedur dengan benar seperti mencari $U_{1}$ terlebih dahulu barulah ia mencari $\mathrm{S}_{6}$. Sehingga DS mendapatkan hasil sesuai dengan perhitungan yaitu 728 .

Pada langkah berikutnya, DS melanjutkan ke memeriksa kembali jawaban. Berdasarkan Gambar 2 siswa tersebut telah membuat kesimpulan ataupun memeriksa kembali penyelesaian tersebut. Artinya, terjadi peningkatan kemampuan pemecahan masalah siswa yang disebabkan karena model Problem Based Learning memungkinkan siswa dapat meningkatkan kemandirian dalam berpikir menganalisa permasalahan. Pendapat ini sejalan dengan pendapat Gagne (dalam Amir, 2009:45) menyatakan "kemampuan pemecahan masalah merupakan seperangkat prosedur atau strategi yang memugkinkan seseorang dapat meningkatkan kemandirian dalam berpikir".

Terdapat 23 orang siswa yang tergolong berkemampuan sedang setelah diberi ujian tes akhir, 5 orang diantaranya menurun menjadi siswa berkemampuan 
rendah. Lembar jawaban salah satu siswa yang berinisial MR dapat dilihat pada Gambar 3.

Berdasarkan hasil ujian tes akhir salah satu siswa yang berinisial yang awalnya tergolong berkemampuan sedang menurun menjadi siswa berkemampuan rendah. Hal ini disebabkan oleh MR tidak memahami apa permasalahan pada soal. MR membuat apa yang diketahui dan ditanya tetapi tidak tepat. Sehingga ia tidak dapat menuliskan rencana penyelesaian. Pada langkah penyelesaian, MR langsung saja menuliskan jawaban tanpa menuliskan rumus terlebih dahulu, sehingga hasil yang didapatkan salah. Pada tahap memeriksa kembali jawaban, ia tidak menuliskan kesimpulan ataupun melakukan pengecekan kembali hasil jawaban.

Hasil wawancara dengan $M R$, ia mengatakan bahwa "saya tidak mengerti

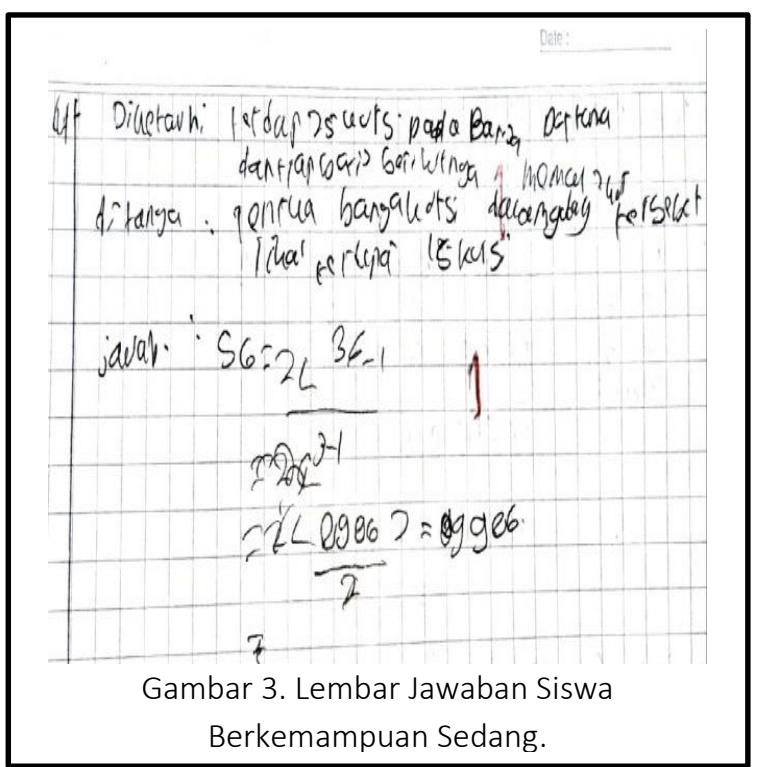

soal nomor 4 ini buk, soalnya terlalu susah. Saya hanya menyalin punya teman buk". Hasil jawaban MR tidak jauh berbeda dengan MS. Jadi dapat disimpulkan bahwa siswa yang awalnya tergolong berkemampuan sedang menurun menjadi siswa berkemampuan rendah dikarenakan siswa tersebut kurang memahami apa yang dimaksud pada soal, sehingga ia kesulitan ketika membuat perencanaan masalah terlebih dahulu, sehingga ketika ia membuat penyelesaian hasil yang didapatkan salah.

\section{c. Siswa Berkemampuan Rendah}

Berdasarkan nilai ujian semester 2, siswa yang tergolong ke dalam berkemampuan Rendah ada 4 orang. Setelah diberikan ujian tes akhir siswa yang tergolong pada berkemampuan rendah ada 6 orang. Tetapi, 3 diantara 4 siswa yang awalnya tergolong berkemampuan rendah meningkat

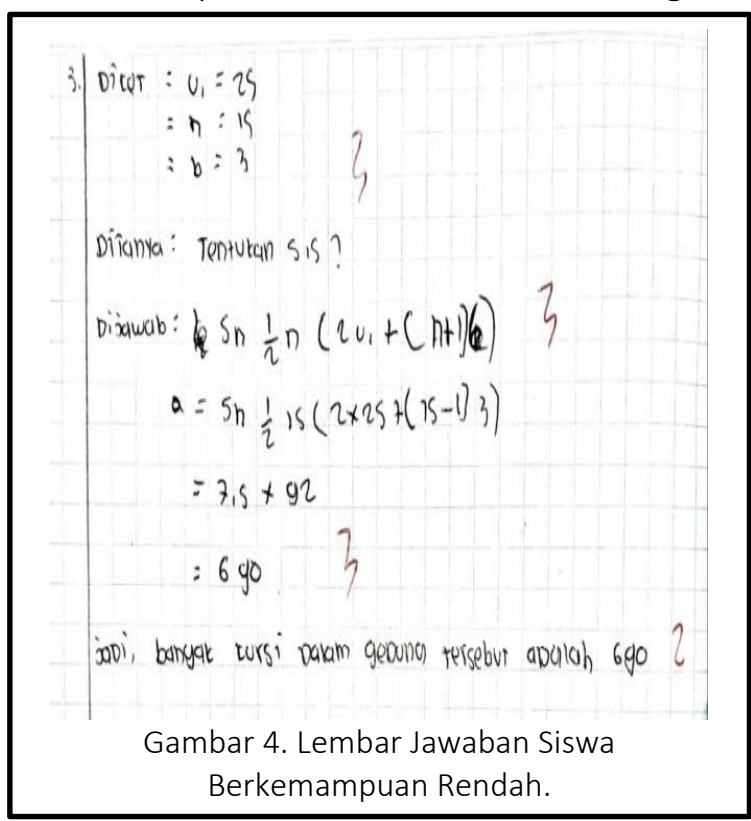


http://journal.institutpendidikan.ac.id/index.php/mosharafa

menjadi berkemampuan rendah

meningkat menjadi siswa berkemampuan sedang. Sebagaimana dapat dilihat dari jawaban salah satu siswa yang berinisial DM pada Gambar 4.

Berdasarkan Gambar 4 siswa tersebut sudah dapat memahami masalah. DM sudah dapat memahami permasalahan secara menyeluruh dengan menuliskan apa yang diketahui dan apa yang ditanya. Selanjutnya, DM sudah dapat menyusun rencana penyelesaian, ia sudah dapat menyajikan langkah penyelesaian yang benar dengan menuliskan rumus terlebih dahulu. Lalu, pada langkah menyelesaikan rencana penyelesaian, DM sudah mampu menyelesaikan permasalahan dengan benar. Sehingga, DM dapat menemukan hasil jawaban yang benar yaitu 690 kursi. Lalu, ia menulis kesimpulan dan melakukan pengecekan terhadap proses dengan tepat. Sejalan dengan (Warsono, 2013; Rinaldi \& Afriansyah, 2019) bahwa problem based learning dapat meningkatkan kemampuan pemecahan masalah matematis siswa dan juga dapat membuat siswa menjadi lebih aktif.

\section{Penutup}

Berdasarkan dari hasil analisis dan pembahasan maka dapat disimpulkan bahwa kemampuan pemecahan masalah dengan Problem Based Learning menjadi lebih baik. Dalam penelitian ini siswa dikelompok berdasarkan KAM. KAM merupakan kemampuan awal matematis siswa yang terbagi dari 3 kategori yaitu
KAM tinggi, KAM sedang dan KAM rendah. Siswa yang awalnya tergolong KAM rendah, 75\% meningkat menjadi KAM sedang, 25\% tetap menempati posisi yang sama. Siswa yang awalnya tergolong KAM sedang, 26\% diantaranya meningkat menjadi KAM tinggi. Tetapi, 21\% siswa menurun menjadi KAM rendah dan 52\% tetap menempati posisi yang sama. Lalu, siswa yang awalnya tergolong KAM tinggi, $40 \%$ menurun menjadi KAM sedang dan $60 \%$ diantaranya menempati posisi yang sama. Mereka sudah mampu 1) memahami masalah, 2) menyusun rencana penyelesaian, 3) melaksanakan penyelesaian, dan 4) mengecek kembali jawaban.

\section{DAFTAR PUStaka}

Afriansyah, E. A. (2014). What Students' Thinking about Contextual Problems is. International Seminar on Innovation in Mathematics and Mathematics Education. Innovation and Technology for Mathematic, 279288. Department of Mathematics Education Faculty of Mathematics and Natural Science Yogyakarta State University.

Afriansyah, E. A. (2016). The Use of Realistic Approach to Enhance Students' Mathematical Problem Solving Skills. International Conference on Elementary and Teacher Education ICETE.

Afriansyah, E. A., Puspitasari, N., Luritawaty, I. P., Mardiani, D., 
Sundayana, R. (2019). The analysis of mathematics with ATLAS.ti. Journal of Physics: Conference Series, 1402(7), 077097.

Ariani, S., Hartono, Y., \& Hiltrimartin, C. (2017). Kemampuan Pemecahan Masalah Matematika Siswa Pada Pembelajaran Matematika Menggunakan Strategi AbduktifDeduktif Di Sma Negeri 1 Indralaya Utara. 3(1), 25-34.

Arikunto, S. (2010). Prosedur Penelitian. Jakarta: Rineka Cipta.

Asih, N., \& Ramdhani, S. (2019). Peningkatan Kemampuan Pemecahan Masalah Matematis dan Kemandirian Belajar Siswa Menggunakan Model Pembelajaran Means End Analysis. Mosharafa: Jurnal Pendidikan Matematika, 8(3), 435-446. DOI: https://doi.org/10.31980/moshar afa.v8i3.534

Burton, L. (1980). The teaching of mathematics to young children using a problem solving approach. Educational Studies in Mathematics, 11(1), 43-58. https://doi.org/10.1007/BF00369159. Depdiknas. (2001). Penyusunan Butir Soal dan Instrumen Penelitian. Jakarta: Depdiknas.

Elita, G., Habibi, M., Putra, A., \& Ulandari, N. (2019). Pengaruh Pembelajaran Problem Based Learning dengan Pendekatan Metakognisi terhadap
Kemampuan Pemecahan Masalah

Matematis. Mosharafa: Jurnal Pendidikan Matematika, 8(3), 447458.

DOI: https://doi.org/10.31980/moshar afa.v8i3.517

Gais, Z., \& Afriansyah, E. A. (2017). Analisis Kemampuan Siswa dalam Menyelesaikan Soal High Order Thinking Ditinjau dari Kemampuan Awal Matematis Siswa. Mosharafa: Jurnal Pendidikan Matematika, 6(2), 255-266.

Gunantara, G., Suarjana, M., \& Riastini, P. N. (2014). Penerapan Model Pembelajaran Problem Based Learning untuk Meningkatkan Kemampuan Pemecahan Masalah Matematika Siswa Kelas V. Jurnal Mimbar PGSD Universitas Pendidikan Ganesha, 2(1), 1-10. https://doi.org/10.1073/pnas.070399 3104

Hidayatullah, A. (2012). Pengaruh Pembelajaran Matematika Dengan Promlem Based Learning (PBL) Terhadap Kemampuan Berpikir Kritis Siswa. Jakarta.

Johar, R. (2011). Domain Soal PISA untuk Literasi Matematika. 1(1), 30-41.

Lie, A. (2002). Cooperative Learning Mempraktikan Cooperative Learning di Ruang-Ruang Kelas. Jakarta: PT Gramedia Widiasarana Indonesia. 
http://journal.institutpendidikan.ac.id/index.php/mosharafa

Muliyardi. 2002. Strategi Pembelajaran Matematika. Padang: Universitas Negeri Padang

Moleong, L . (2010). Metodologi Penlitan Kualitatif. Bandung: Remaja Rosda Karya.

Rinaldi, E., \& Afriansyah, E. A. (2019). Perbandingan

Kemampuan

Pemecahan Masalah Matematis Siswa antara Problem Centered Learning dan Problem Based Learning. NUMERICAL: Jurnal Matematika dan Pendidikan Matematika, 9-18.

Sopian, Y., \& Afriansyah, E. A. (2017). Kemampuan Proses Pemecahan Masalah Matematis Siswa Melalui Model Pembelajaran Creative Problem Solving Dan Resource Based Learning. Jurnal Elemen, 3(1), 97-107.

Sumarmo, U. (1994). Suatu Alternatif untuk Meningkatkan Kemampuan Pemecahan Masalah Matematika pada Guru dan Siswa SMP. Bandung

Sumartini, T. S. (1981). Peningkatan Kemampuan Penalaran Matematis Siswa Melalui Pembelajaran Berbasis Masalah. Folia Morphologica, 29(4), 336-338.

https://doi.org/http://dx.doi.org/10.3 1980/mosharafa.v4i1.239.g244

Suprihatiningrum, J. (2013). Strategi Pembelajaran (1st ed.; Rose Kusumaning Ratri, ed.). Jogjakarta: AR-RUZZ MEDIA.

Utami, R. W., \& Wutsqa, D. U. (2017). Analisis kemampuan pemecahan masalah matematika dan self-efficacy siswa SMP negeri di Kabupaten Ciamis. Jurnal Riset Pendidikan Matematika, 4(2), 166. https://doi.org/10.21831/jrpm.v4i2.14 $\underline{897}$

Upu, H. (2003). Problem Posing dan Problem Solving. Bandung: Pustaka Ramadhan.

\section{Riwayat Hidup PENULIS}

Mulia Suryani, M.Pd.

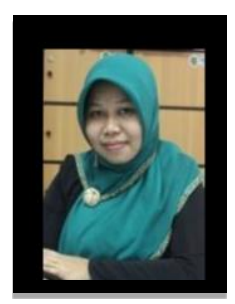

Lahir di Padang, 12 November 1987. Dosen tetap yayasan STKIP PGRI Sumatera Barat. Menjabat sebagai Lektor/Penata di Program Studi Pendidikan Matematika. Studi $\mathrm{S}_{1}$ Pendidikan Matematika STKIP PGRI Sumatera Barat, lulus tahun 2009. Studi $S_{2}$ Konsentrasi Program Studi Pendidikan Matematika Pasca Sarjana UNP, lulus tahun 2012.

Lucky Heriyanti Jufri, S.Si., M.Pd.

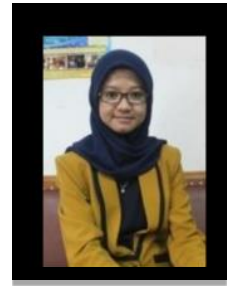
Lahir di Padang, 12 Agustus 1987. Dosen tetap yayasan STKIP PGRI Sumatera Barat. Studi $S_{1}$ Matematika di Universitas Pendidikan Indonesia, Studi $S_{2}$ Pendidikan Matematika di Universitas Pendidikan Indonesia.

\section{Tika Artia Putri}

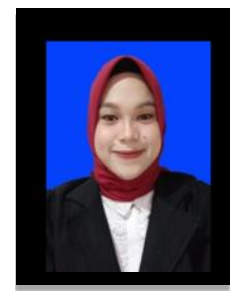

Lahir di Padang, 12 Mei 1997. Studi $\mathrm{S}_{1}$ Pendidikan Matematika STKIP PGRI Sumatera Barat, lulus tahun 2019. 